\title{
Seroclearance of hepatitis B surface antigen following hepatitis $E$ exacerbation on chronic hepatitis $E$ and $B$ dual infection in a renal transplant recipient: a case report
}

\author{
Chau-Ting Yeh $^{1 *}$ D, Christopher Sung-Huan Yeh ${ }^{2}$, Yu-De Chu ${ }^{1}$ and Yang-Jen Chiang ${ }^{3}$
}

\begin{abstract}
Background: Hepatitis E virus infection usually causes an acute and self-resolving hepatitis. In areas where chronic hepatitis B virus infection is prevalent, acute hepatitis $E$ virus superinfection on chronic hepatitis B virus infection occurs sporadically. In recent years, however, chronic hepatitis E virus infection has been recognized in patients under immunosuppressant therapy. To the best of our knowledge, cases involving patients with chronic hepatitis $E$ virus and hepatitis B virus dual infection have never been reported.

Case presentation: A 47-year-old Taiwanese woman who was a renal transplant recipient with chronic hepatitis B virus infection was under immunosuppressant and antiviral treatment. An episode of hepatitis B exacerbation developed due to withdrawal of antiviral treatment against advice, but the flare subsided following antiviral re-treatments. However, an episode of hepatitis exacerbation developed following removal of the renal graft because of graft failure. During the hepatitis flare, she was still under successful antiviral suppression against hepatitis B virus, while her serum samples were positive for hepatitis E virus RNA. Following the hepatitis flare, seroclearance of hepatitis B virus surface antigen developed. From then on, she was under regular hemodialysis. Five years later, another episode of mild hepatitis exacerbation occurred again with positive serum hepatitis E virus RNA. Tracing back the longitudinal serum samples, serum hepatitis E virus RNA was persistently positive throughout the course. This patient was thus recognized to have chronic hepatitis $E$ virus and hepatitis B virus dual infection with intermittent hepatitis E exacerbations.
\end{abstract}

Conclusions: In areas where chronic hepatitis B virus infection is prevalent, chronic hepatitis E virus coinfection can occur in organ transplant recipients receiving immunosuppressant. Intermittent hepatitis E exacerbations may develop, interfering with the status of hepatitis B virus infection.

Keywords: Hepatitis B, Hepatitis E, Coinfection

\section{Background}

Chronic hepatitis E virus (HEV) infection has been reported in immunocompromised patients [1]. In Asia, where hepatitis B virus (HBV) infection is highly prevalent, acute HEV superinfection on chronic HBV infection could occur sporadically. However, patients with dual chronic HEV and HBV infection have never been documented.

\footnotetext{
* Correspondence: chautingy@gmail.com

'Liver Research Center, Chang Gung Memorial Hospital, 5, Fu-Shin Street,

Kuei-Shan District, Taoyuan, Taiwan

Full list of author information is available at the end of the article
}

Here, we reported a renal transplant recipient, who had dual chronic HEV and HBV infection. Interestingly, following an episode of acute hepatitis $\mathrm{E}$ exacerbation, seroclearance of HBV surface antigen ( $\mathrm{HBsAg}$ ) developed and our patient achieved a "functional cure" for chronic HBV infection.

\section{Case presentation}

A 47-year-old Taiwanese woman, a housewife, who was an $\mathrm{HBV}$ carrier, had received renal transplantation in 2002 and was treated with an immunosuppressant. 
Lamivudine was provided to maintain virological suppression for HBV. She was referred to the Liver Clinic of Chang Gung Memorial Hospital in January 2004 due to elevated HBV DNA levels $\left(31.2 \times 10^{6}\right.$ copies $\left./ \mathrm{mL}\right)$. She denied major systemic diseases other than chronic hepatitis B and renal disease. No documented hereditary diseases or psychological disorders in her family were noted. She had an average socioeconomic status. On physical examination, she appeared normal with no icteric sclera, no hepatosplenomegaly, no spider nevi, and no caput medusae. She was positive for HBsAg, negative for $\mathrm{HBV}$ e antigen ( $\mathrm{HBeAg}$ ), and positive for anti-HBe antibody. No clinical evidence of liver cirrhosis was noted. Genotypic analysis revealed genotype B, precore stop codon G1896A mutation (+), basal core promoter mutation (-), and rtM204V/rtL180M mutation $(+)$. She was switched to adefovir monotherapy and HBV DNA declined rapidly (Fig. 1, lower panel). HBV DNA became undetectable in August 2007. She stopped antiviral treatment in February 2008 against advice. However, relapse of viremia $\left(29.3 \times 10^{6}\right.$ copies $\left./ \mathrm{mL}\right)$ developed and she was treated with lamivudine again for no detectable genotypic resistance (insurance coverage policy), but switched to adefovir shortly afterwards because of emergence of rtM204V/rtL180M mutants accompanied by a mild hepatitis flare: alanine transaminase (ALT) $49 \mathrm{U} / \mathrm{L}$.

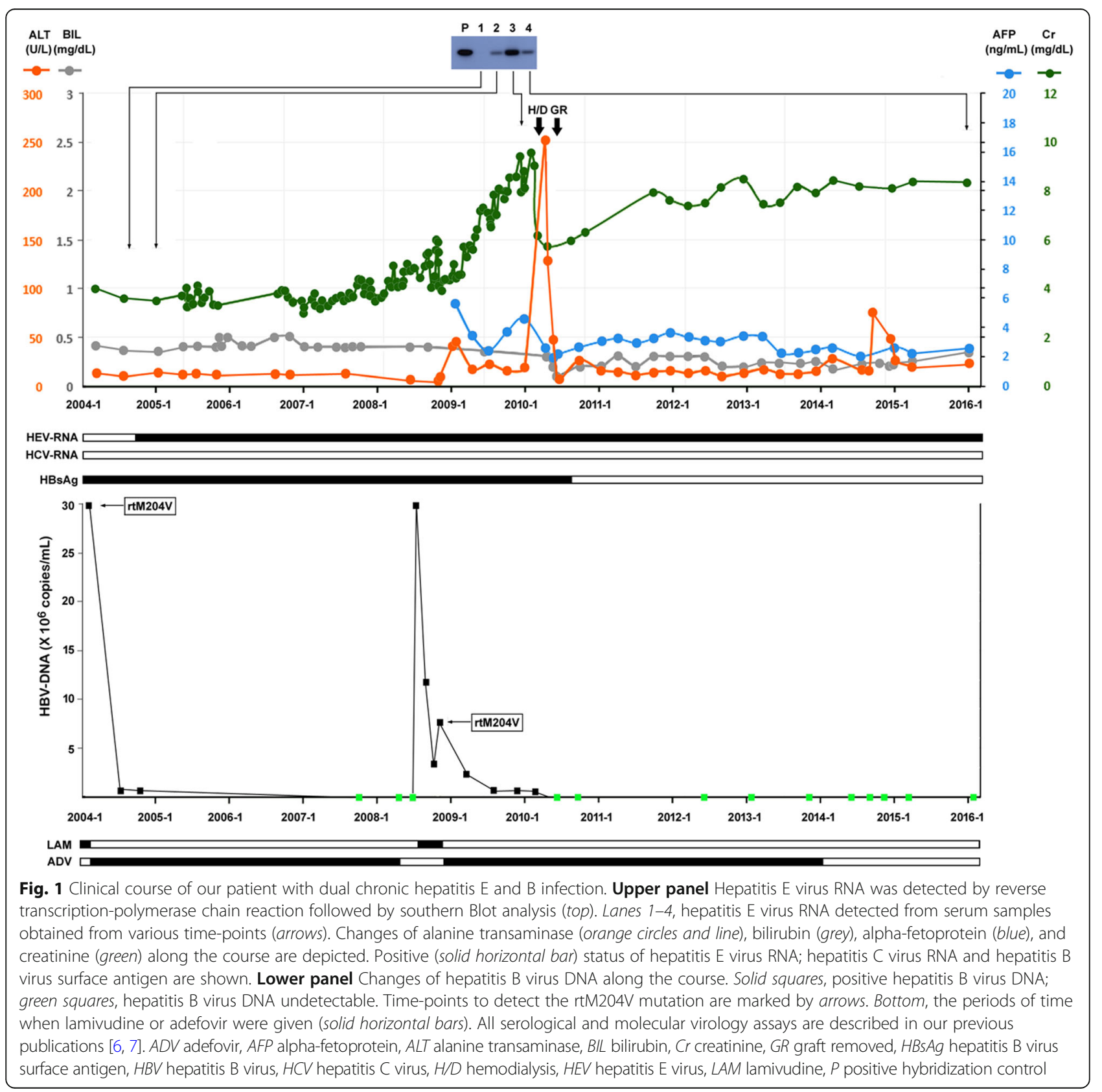


From then on, maintained suppression of HBV DNA was achieved. HBV DNA was undetectable since March 2010. The flares in 2004 and late 2008 were considered flares of hepatitis $B$ because of the accompanied elevations of HBV DNA levels with normalization of ALT after suppression of HBV DNA.

Our patient suffered from graft rejection after renal transplantation and was treated with immunosuppressant drugs, including tacrolimus ( $3 \mathrm{mg} /$ day), mycophenolate mofetil (500 $\mathrm{mg}$ twice a day), and prednisolone (10 mg/day). Her creatinine levels were between 3 and 4 $\mathrm{mg} / \mathrm{dL}$ initially, but gradually elevated to $10 \mathrm{mg} / \mathrm{dL}$ despite increasing dosage of immunosuppressants. In January 2010, obstruction of graft ureter was found and hemodialysis resumed. Immunosuppressants were withdrawn and an episode of hepatitis flare occurred with ALT elevation to $251 \mathrm{U} / \mathrm{L}$. After normalization of ALT, the renal graft was removed by operation. No HBV DNA elevation was detected before and during the flare. Throughout the flare, HBV DNA was suppressed to less than $10^{4}$ copies/mL by adefovir. No known hepatotoxic drug was in use during this period. Anti-hepatitis $\mathrm{C}$ virus (HCV) antibody was positive since January 2008 but HCV RNA was negative throughout the clinical course. IgM anti-hepatitis A virus antibody, anti-hepatitis D virus (HDV) antibody, and HDV RNA were all tested negative. Subsequently, HEV RNA was found to be positive by reverse transcription-polymerase chain reaction (RT-PCR) and Southern blot analysis (Fig. 1, upper panel). Sequence analysis revealed genotype 3 . Positive HEV RNA could be traced back to January 2005 but before that it was negative. Strikingly, seroclearance of HBsAg occurred in July 2010. Before this flare, the quantitative level of HBsAg was $25,000 \mathrm{IU} / \mathrm{mL}$. It remained negative thereafter and adefovir was stopped in January 2014 with no subsequent virological relapse. Another episode of ALT elevation (to 73 U/L) was found during October to November 2014 with no positive hepatitis A to D markers. HEV RNA continued to be positive (final check was performed in January 2016). IgG anti-HEV was positive. Ribavirin was not given because of the low hemoglobin level in this patient who received hemodialysis. Anti-HBs antibody was negative throughout the course.

\section{Discussion}

Chronic HBV infection is highly prevalent in Asia. Therefore, acute but self-resolving HEV superinfection on chronic HBV infection can occur sporadically [2,3]. Because chronic HEV infection can develop in patients under immunosuppressants, dual chronic HEV and HBV infection should be found in patients receiving organ transplantation, especially in an HBV endemic area. Here we identified a renal transplant recipient with chronic dual HEV and HBV infection. In this reported case of a patient, the dual chronic hepatitis infection was mostly asymptomatic during the clinical course. At that time, HBV infection was controlled by either lamivudine or adefovir monotherapy (if resistance developed), but not by add-on therapy because of high cost of adefovir. In this patient, HBV DNA could be suppressed to a low or undetectable level. The actual cause of hepatitis exacerbation preceded by HEV RNA elevation in January 2010 was unknown. A previous study showed that calcineurin inhibitors promoted HEV replication but mycophenolic acid inhibited HEV replication [4]. A disproportionate increase of the two immunosuppressants during graft rejection could result in fluctuating levels of HEV replication. On the other hand, withdrawal of immunosuppressant agents could increase host immune responses, and partly contribute to the exacerbation. No other causes of hepatitis could be identified other than HEV-related hepatitis flare. It is inspiring to find that HBsAg seroclearance could develop following a HEV-related hepatitis flare. Current clinical trials for new anti-HBV therapies are following a strategy similar to this scenario, where patients were under antiviral treatment to suppress HBV DNA and a novel immune-related agent or a new strategy to perturb immune responses was applied to induce seroclearance of $\mathrm{HBsAg}$. Seroclearance of HBsAg was considered a "functional cure" for HBV infection [5]. It is worth noting that HEV-induced immune response can result in HBsAg clearance.

A second episode of mild hepatitis $\mathrm{E}$ exacerbation developed 5 years after the removal of the renal graft and withdrawal of immunosuppressant. Our patient was under regular hemodialysis at that time and remained persistently positive for serum HEV RNA.

\section{Conclusions}

This case report revealed that chronic dual HEV and HBV infection could occur in areas where hepatitis B is prevalent. Hepatitis exacerbations of HEV were noted, resulting in seroclearance of HBsAg. Serum HEV RNA persisted even after immunosuppressant was stopped, while our patient was under hemodialysis.

\section{Abbreviations \\ ALT: Alanine transaminase; HBeAg: Hepatitis B virus e antigen; HBsAg: Hepatitis B virus surface antigen; HBV: Hepatitis B virus; HCV: Hepatitis C virus; HDV: Hepatitis D virus; HEV: Hepatitis E virus; RT-PCR: Reverse transcription-polymerase chain reaction}

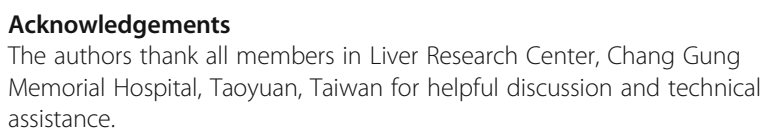

Funding

This study was supported by grants from Chang Gung Medical Research Program (CRRPG3F0051 and CRRPG3E0101). 


\section{Availability of data and materials}

All data generated or analyzed during this study are included in this published article.

\section{Authors' contributions}

CTY and CSHY carried out the literature research, manuscript preparation, and were the main moderators of the manuscript. Y-DC revised the manuscript. CTY and YJC collected and interpreted all clinical data of the patient. All authors read and approved the final manuscript.

\section{Ethics approval and consent to participate}

Written consent was obtained from the patient for all serological assays. Anonymous case report was conducted in accordance with the requirement of Chang-Gung Memorial Hospital Ethics Committee.

\section{Consent for publication}

Written informed consent was obtained from the patient for publication of this case report and any accompanying images. A copy of the written consent is available for review by the Editor-in-Chief of this journal.

\section{Competing interests}

The authors declare that they have no competing interests.

\section{Publisher's Note}

Springer Nature remains neutral with regard to jurisdictional claims in published maps and institutional affiliations.

\section{Author details}

${ }^{1}$ Liver Research Center, Chang Gung Memorial Hospital, 5, Fu-Shin Street, Kuei-Shan District, Taoyuan, Taiwan. ${ }^{2}$ Department of Cognitive Science, College of Letters and Science, University of California Los Angeles, Los Angeles, USA. ${ }^{3}$ Department of Urology and Renal Transplantation, Chang Gung Memorial Hospital, Taoyuan, Taiwan.

Received: 29 August 2017 Accepted: 27 January 2018

Published online: 28 February 2018

\section{References}

1. Fujiwara S, Yokokawa Y, Morino K, Hayasaka K, Kawabata M, Shimizu T. Chronic hepatitis E: a review of the literature. J Viral Hepat. 2014;21 (2):78-89.

2. Singh NJ, Kumari A, Catanzaro R, Marotta F. Prevalence of hepatitis E and hepatitis B dual infection in North India (Delhi). Acta Bio Medica Atenei Parmensis. 2013;83(3):197-201.

3. Hoan NX, Tong HV, Hecht N, Sy BT, Marcinek P, Meyer CG, Song le H, Toan NL, Kurreck J, Kremsner PG, et al. Hepatitis E Virus Superinfection and Clinical Progression in Hepatitis B Patients. EBioMedicine. 2015;2(12):2080-6.

4. Wang Y, Zhou X, Debing Y, Chen K, Van Der Laan $\sqcup$, Neyts J, Janssen HL, Metselaar HJ, Peppelenbosch MP, Pan Q. Calcineurin inhibitors stimulate and mycophenolic acid inhibits replication of hepatitis E virus. Gastroenterology. 2014;146(7):1775-83.

5. Liang TJ, Block TM, McMahon BJ, Ghany MG, Urban S, Guo JT, Locarnini S, Zoulim F, Chang KM, Lok AS. Present and future therapies of hepatitis B: From discovery to cure. Hepatology. 2015;62(6):1893-908.

6. Yeh CT, Tsao ML. Detection of serum anti-NV-F antibodies in the convalescent phase of severe hepatitis in patients positive for tissue NV-F antigen and novel virus-like particles. J Med Virol. 2015;87(10):1727-36.

7. Lai MW, Lin TY, Tsao KC, Huang CG, Hsiao MJ, Liang KH, Yeh CT. Increased seroprevalence of HBV DNA with mutations in the s gene among individuals greater than 18 years old after complete vaccination. Gastroenterology. 2012;143(2):400-7.

\section{Submit your next manuscript to BioMed Central and we will help you at every step:}

- We accept pre-submission inquiries

- Our selector tool helps you to find the most relevant journal

- We provide round the clock customer support

- Convenient online submission

- Thorough peer review

- Inclusion in PubMed and all major indexing services

- Maximum visibility for your research

Submit your manuscript at www.biomedcentral.com/submit
Biomed Central 